\title{
THE PALAEOPATHOLOGY OF THE VERTEBRAL COLUMN IN ANCIENT EGYPT AND NUBIA
}

by

\section{J. B. BOURKE}

The Cradle of the history of medicine in the Old World is to be found in Ancient Egypt and Nubia. Abundant data is available from medical papyri, mummies, osseous remains, literature and art and extends from prehistoric to Graeco-Roman times. The range of pathological processes afflicting the Ancient Egyptians and Nubians has been extended with the description of more material. However, most excavators, particularly those in the period 1890 to 1920 paid little attention to the bones of the post cranial skeleton unless the changes were gross and this has restricted our knowledge of their pathology (Salib, 1967). Even if all post cranial bones were examined by the most modern techniques, the palaeopathologist is still limited by the number of ways bone can react to a pathological stimulus. Thus, only tentative conclusions may be possible, yet they can be extended if soft tissue was also present (Bourke, 1967; Sandison, 1968).

The building of the Aswan Dam has stimulated further anthropological and palaeopathological study of these peoples and provoked reassessment of many aspects of their culture and biology. In this paper the palaeopathology of the vertebral column from prehistoric to Roman times will be discussed and an attempt made to evaluate the present extent of our knowledge.

The vertebral column is comprised of the cervical, thoracic and lumbar vertebrae as well as the sacrum and coccyx. The palaeopathology will be discussed using Wells' classification (1964):

A. CONGENITAL DISEASE

1. Genetic

2. Intra-uterine malformation.

B. ACQUIRED DISEASE

1. Trauma

2. Degenerative diseases

3. Neoplasia

4. Non-specific infections

5. Specific infections

6. Endocrine and metabolic disorders.

CONGENITAL DISEASE

1. Genetic Disease

Brothwell and Powers (1968) commented upon the difficulty of establishing the true frequency of congenital malformations in man. This was well demonstrated in the 


\section{J. B. Bourke}

vertebral column of Ancient Egyptians and Nubians as the majority of specimens were never saved or studied (Elliot Smith and Wood Jones, 1910; Salib, 1967).

Elliot Smith and Wood Jones (1910), however, have partly remedied this defect. They found six examples of assimilation of the atlas into the occiput out of 6,000 Nubian specimens. Great variation in the characteristics of the lateral masses of the atlas and the foramina for the vertebral artery were recorded but no incidence was given. Congenital fusion of vertebrae was also found in all regions of the vertebral column and six examples of cervical rib were reported.

In achondroplasia, a genetic dominant disease, the length of the vertebral column is normal, but the ossification centres of the vertebral bodies may be smaller than normal. Often a long regular kyphosis in the dorso-lumbar region may be present. Occasionally all the lumbar vertebrae are included in the kyphosis and the sacrum can be horizontal. Early synostosis between the vertebral body and the neural arch can occur and it may be so severe that there is a marked reduction in vertebral canal size (Mercer and Duthie, 1964).

Several examples of dwarfs were described in Ancient Egypt and Nubia and attributed to achondroplasia. A sixth-dynasty carving of Seneb at Gizah showed a dwarf contrasted with normal-sized wife and children. Further drawings of dwarfs were found on a fifth-dynasty tomb at Deshasheh. Ruffer (1911) reported the fifthdynasty statuette of Chnoum-hotep from Saqqarah and also a predynastic drawing of the 'dwarf of Zer' from Abydos. Osseous remains attributable to achondroplasia were reported by Jones (1932), Bleyer (1940) and Maciver (1901), but changes in the vertebral column were not noted. This relative profusion of dwarfs may be explained by the exalted position which they occupied at court (Johnston, 1963).

Rowling (1967) reported on two femora, two radii and ulnae, pelvis, sacrum and lumbar vertebrae from a predynastic individual of Nubia. The sacrum and lumbar vertebrae were noted to be dense and hard; and a posterior defect in the neural arch was present in the upper two sacral segments. Rowling concluded that these changes could result from ectopic ossification secondary to paraplegia, but Brothwell (1967b) rejected this and suggested osteogenesis imperfecta (a genetic dominant disease) as a possible diagnosis.

\section{Intra-uterine Malformation}

Barclay-Smith (1911) reported in detail the remains of an incomplete skeleton of a young adult female from Saqqarah. It was inadequately dated and may be Ptolemaic or earlier. All regions of the vertebral column showed anomalies. For example there were eight cervical vertebrae with synostosis of the atlas to the occiput. The axis and third cervical vertebra were fused into one mass. The thoracic region showed the opposed articular facets of the eleventh and twelfth vertebrae to be lumbar in type. The lumbar vertebrae and sacrum were scoliotic and part of the neural arch of the fifth lumbar vertebra was an independent ossicle. The opinion was advanced that these changes resulted from excessive use. Wells (1964), however, was of the opinion that it was an example of the Klippel-Feil syndrome: a developmental defect of mesoderm.

Brothwell and Powers (1968) reported a possible example of anencephaly in a well-preserved Egyptian mummy from the catacombs at Hermopolis. They reproduced 


\section{Palaeopathology of the Vertebral Column in Ancient Egypt and Nubia}

the original drawings and study of them suggested that the upper region of the vertebral column may show non-union of the neural arches. Further examination of this mummy including radiological study is required before it may be accepted with conviction.

\section{ACQUIRED DISEASE}

\section{Trauma}

The earliest written clinical record was produced in Ancient Egypt and Nubia as two medical documents or papyri which were discovered in 1862. Dawson (1932) has related how they were found and commented upon the confusion over their titles. The Ebers Papyrus, originally the better-known document, is a collection of extracts from about forty different sources. It contained a few sections on symptoms and diagnosis and the concluding part was surgical, relating to the treatment of wounds and sores. Dawson dismissed it as being without merit as a scientific medical record.

The second or Edwin Smith Papyrus (Breasted, 1930) has two distinct parts. It was written between 3,000 and 2,500 B.C. when the pyramids were being built. The first part was a surgical handbook which contained much information about the treatment of traumatic lesions, particularly those of the skull and vertebral column: the second being a miscellaneous collection of recipes and charms similar to the bulk of the Ebers and other papyri (Dawson, 1932 and 1953) and need not concern us further.

Traumatic injury to the vertebral column is extensively described in the first part of the Edwin Smith Papyrus. Unfortunately the text is incomplete and breaks off in mid-sentence. Dawson (1932 and 1953) suggested that the present papyrus is but a copy of the original. It recorded the details of over forty-eight wounds and fractures classified in an orderly manner from head to foot in the style of the later Greek medical books. Details are presented in the systematic order of title, examination, diagnosis, prognosis and treatment. Jottings are present and Power (1933) attributed them to a seventeenth-century B.C. surgeon who added them to the original text. The full significance of each description may only become apparent when they are interpreted. However, this has not always resolved doubt (Dawson, 1932).

The nature of the jottings suggested that the writer was stimulated to investigate patients he could not cure and Jones (1922) noted that the scientific rather than the physicianly attitude was adopted: more attention was given to the natural history of the injury than to diagnosis.

Case 31 of the Papyrus detailed a dislocation of the cervical column with an associated injury of the spinal cord (Breasted, 1930):

Instructions concerning a dislocation in a vertebra of his neck. If thou examinest a man having a dislocation in a vertebra of his neck, shouldest thou find him unconscious of his two arms and his two legs on account of it, whilst his penis is erect on account of it and urine drops from his member without his knowing it; his flesh has received wind; his two eyes are bloodshot. It is a dislocation of the vertebra of the neck extending to his backbone which causes him to be unconscious of his two arms and his two legs. If, however, the middle vertebra of his neck is dislocated it is an emissio seminis which befalls his penis. Thou shouldest say concerning him 'One having a dislocation in a vertebra of his neck while he is unconscious of his two legs and his two arms and his urine dribbles. An ailment not to be treated'. 


\section{J. B. Bourke}

In the above account priapism was noted and ileus recorded. Further examples showed that the author was able to distinguish between the dislocation of a cervical vertebra with and without an associated injury of the spinal cord. In one example it is noted (Breasted, 1930):

Instructions concerning a displacement in a vertebra in his neck. If thou examinest a man having a displacement in a vertebra of his neck, whose face is fixed, whose neck cannot turn for him and thou shouldest say to him 'Look at thy breast and thy two shoulders' and he is unable to turn his face that he may look at his breast and his two shoulders. Thou shouldest say concerning him 'One having a displacement in a vertebra of his neck. An ailment which I will treat'.

This is a description of a sprain of the cervical column (Power, 1933). Subsequently a fracture dislocation was described thus (Breasted, 1930):

Instructions concerning a crushed vertebra in his neck. If thou examinest a man having a crushed vertebra in his neck and thou findest that one vertebra has fallen into the next one, while he is voiceless and cannot speak; his head falling downwards, has caused that one vertebra crush into the next one; and shouldest thou find that he is unconscious of his two arms and his two legs because of it Thou shouldest say concerning him 'One having a crushed vertebra in his neck; he is unconscious of his two arms and his two legs and he is speechless. An ailment not to be treated'.

The above passage also included a description of a crush fracture of a cervical vertebra. These descriptions which were made about 4,500 years ago have not been improved upon in their basic conception of the nature of the injury and their effect.

Several examples of skull fractures were recorded and the development of neck stiffness was accurately described (Breasted, 1930):

If thou examinest a man having a gaping wound in his head penetrating to the bone, and smashing his skull: thou shouldest palpate his wound. Shouldest thou find that smash which is in his skull deep and sunken under thy fingers whilst the swelling which is over it protrudes, he discharges blood from both his nostrils and both his ears and he suffers with stiffiness in his neck so that he is unable to look at his two shoulders and his breast. Thou shouldest say regarding him 'One having a gaping wound in his head penetrating to the bone and smashing his skull while he suffers with stiffness in his neck. An ailment not to be treated'.

Neck stiffness could be associated with the original injury but alternatively it might be secondary to meningitic infection.

Case 48, the last case of the papyrus noted a sprain in the spinal column and examination of the patient by straight-leg raising. The treatment recommended was: "thou shouldest place him flat on his back: thou shouldest make for him ...' and the papyrus then abruptly ended.

The sophistication of the Ancient Egyptians and Nubians in being able to describe, understand and treat the injuries recorded in the Papyrus was marked. Little improvement has been made in the last 4,500 years on the simplicity of their descriptions.

Elliot Smith and Wood Jones (1910) in their survey of Nubia found no example of a healed spinal fracture. However, they reported two specimens with evidence of traumatic injury to the vertebral column. One was an adult woman from Shellal and dated to the late predynastic period. This showed a transverse track through the lower margin of the twelfth thoracic vertebral body. Signs of osteitis were also present 


\section{Palaeopathology of the Vertebral Column in Ancient Egypt and Nubia}

and they suggested that this injury might have been caused by a small spear. The second specimen came from the early predynastic cemetery at Shem Nishai, Dehmit. This showed several grooved wounds on the posterior arch of the atlas and the other cervical vertebrae which were attributed to trauma just prior to death. These specimens merit critical re-examination.

Examples of many individual spinal fractures are preserved in the Nubian collection of the Royal College of Surgeons of England (Rowling, 1967). However, they are interesting isolated specimens and data about the population from which they came is incomplete.

\section{Degenerative Diseases}

The palaeopathology of the degenerative diseases in the vertebral column in Ancient Egypt and Nubia has been confused by muddled terminology and lack of understanding of the anatomy and pathology of the joints involved (Bourke, 1967 and 1971; Wells, 1964; Sandison, 1968). The vertebral column is composed of a line of fibrocartilagenous joints between the vertebral bodies. The articular processes of adjacent vertebrae form synovial joints. Degeneration has different effects in these two types of joint.

Osteophytic outgrowths or lipping occurs at the margins of the vertebral bodies and it has been suggested that osteophytosis should be the name reserved for this pathology (Bourke, 1967 and 1970). Osteoarthritic eburnations occur at the synovial apophyseal joints of the vertebral column. Osteoarthritis may be used to describe the degenerative disease in synovial joints.

Confusion was created by Elliot Smith and Wood Jones (1910) who stated that 'rheumatoid arthritis is par excellence the bone disease of Ancient Egypt and Nubia'. Some assumed that the disease of modern clinical practice was being described, but examination of the original text showed the pathology to be that of osteoarthritis and osteophytosis. Ruffer (1918) added to the difficulty by reporting 'arthritis deformans and spondylitis in Ancient Egyptians'. Examples of osteophytosis with bony ankylosis were reported and interpreted as showing that ankylosing spondylitis, an uncommon disease in modern clinical practice, was rampant. Zorab (1961) examined radiologically eight British Museum bodies of the New Kingdom and Roman Period from Egypt and found no case of ankylosing spondylitis. Osteophytosis was present in four. He noted the different age distributions between osteoarthritis and osteophytosis on the one hand and ankylosing spondylitis on the other. Zorab appeared to think that the spondylitis of former authors corresponded with osteoarthritis and osteophytosis. Sandison (1968) and Wells (1964) concurred with this opinion. However, Rowling (1961) still used the term 'ankylosing spondylitis', but Sandison (1968) noted that the pathology described was that of osteoarthritis and osteophytosis.

Osteoarthritis involving the synovial joints of the vertebral column has been reported by Elliot Smith and Wood Jones (1910), Ruffer (1918), Ruffer and Rietti (1912), and Salib (1962). These were all reports of selected specimens. Armelagos (1969) analysed the incidence of synovial joint arthritis in the vertebral column in a series from Nubia which spanned the period from Meroitic to Christian (350 B.C. to as late as A.D. 1300). He found differences between the various groups and accounted 


\section{J. B. Bourke}

for these by changes in the age structure of those studied. It has been well shown in both modern clinical studies (Kellgren, 1961) and in palaeopathological investigations that osteoarthritis increased with age (Inglemark, Møller-Christensen and Brinch, 1959).

Bourke (1967 and 1971) reported a series of vertebral columns from Ancient Eygpt and Nubia. They were excavated during the 1898 and 1899 seasons. The 1899 part of the collection came from Hou (Petrie, 1901) and was dated to about 1500 B.C. The 1898 material came from various sites and ranged from prehistoric or early dynastic to Roman times. Unfortunately, the material was divorced from the other post cranial bones and the skulls and thus, sexing and ageing were impossible. Pathology other than osteophytosis was excluded from his study.

The specimens from Hou numbered 132 and showed two peaks of severe involvement with osteophytosis; one in the cervical and the other in the lumbar region. The other Egyptian series showed a similar pattern. On account of this similarity both groups were pooled and compared with other data which showed that an Iron Age British Series had a similar pattern to those of the Ancient Egyptians and Nubians. This contrasted with a modern English series from St. Bride's Church in Fleet Street, London, which showed marked severe osteophytosis of the cervical column and also some severe changes in the thoracic and lumbar regions. A similar pattern was reported in modern American Whites (Stewart, 1966). Comparison with Stewart's (1947 and 1966) data for the Eskimos and Pueblo Indians indicated that the latter had a similar osteophytic distribution to that of the Ancient Egyptians and Nubians. However, little osteophytosis was present in the Eskimos except in the lumbar region.

Further analysis of the Egyptian data by Bourke (1971) showed that the area of the vertebral column with the greatest incidence and severity of involvement with osteophytosis was the lumbar region in both the Hou and the pooled Egyptian series. Similar findings were obtained in three other series from England (Bourke, 1971). In spite of some Ancient Egyptian and Nubian vertebral columns showing severe osteophytosis it was unjustified to assume minor or major incapacity (Bourke, 1971).

Armelagos (1969) reported the frequency of osteophytosis in his series and found, in common with other workers, (McKern and Stewart, 1957; Willis, 1924; Inglemark et al., 1959; Bourke, 1967; and Kellgren, 1961) that it increased with age. He also noted that in people who live longer their vertebrae were subjected to stress for a longer period.

With increasing numbers of population studies of the vertebral column, more will become known of the biology of osteoarthritis and osteophytosis. No advance in this field can be made by repeated description of single specimens. The techniques of population biology must be increasingly applied to the skeletal remains from Ancient Egypt and Nubia.

Wells (1964) in his classification included two further diseases, rheumatoid arthritis and ankylosing spondylitis in his group of degenerative diseases. Bourke (1967) was unable to find any example of rheumatoid arthritis. However, examples may have been overlooked as the early stages of the disease may only be detected radiologically. Zorab (1961) in a review of the historical background of ankylosing spondylitis described an X-ray investigation of eight mummies which has been referred to above. 


\section{Palaeopathology of the Vertebral Column in Ancient Egypt and Nubia}

He found no proven case of ankylosing spondylitis. Bourke (1967) reported three examples. One was from Cemetery B at Hou (Petrie, 1901) and the spine was completely ankylosed from the axis to the sacrum. The typical radiological signs including calcification of the anterior spinal ligaments and bony fusion of the apophyseal joints were present. He also described a further case from Hou of six fused mid-thoracic vertebrae and one from the New Race Cemetery at Naqada comprising the five lumbar vertebrae and part of the sacrum. These two examples also showed the characteristic radiological and macroscopical changes of ankylosing spondylitis (Bourke, 1967).

\section{Neoplasia}

In contemporary pathology primary neoplasia in the vertebral column is rare, while secondary deposits are far more common being typically lytic rather than sclerotic. Consequently the disease process that it is desired to study destroys its own evidence. Derry (1909) reported the remains of one Middle Nubian (C Group) burial. The vertebrae, particularly those of the cervical region, were fragmented by a 'rarifying osteitis'. The left humerus, clavicle and scapula and the sternum showed similar lesions. Re-examination of this material is needed before the changes can be accepted as possibly due to secondary neoplasm (Brothwell, 1967a).

Elliot Smith and Derry (1910) reported a middle Nubian male skeleton in which the sacrum had been extensively eroded and suggested that this was caused by rectal cancer or possibly a chordoma.

Elliot Smith and Dawson (1924) illustrated an upper lumber vertebra from Nubia with an ill-defined cavity within the cancellous tissue of its body. The defect was situated in the midline and opened on the anterior surface. They considered this to be tuberculous. Rowling (1960) was critical and suggested that the lesion might be neoplastic. He claimed that the strength of the surrounding bone without inflammatory changes and the position of the lesion being in the body of the vertebra and not in the intervertebral disc region, supported his view. His opinion was that the radiographic appearances were suggestive of a haemangioma or erosion by an aortic aneurysm. Further assessment of these three specimens showing changes that may be attributable to a neoplasm need further study before they can be accepted without reservation.

\section{Non-specific infection}

Many bones from Ancient Egypt and Nubia including those of the vertebral column showed the changes of non-specific inflammation (Ruffer, 1921; Moodie, 1923; Wells, 1964). It was a common condition yet its nature and significance have remained obscure. Wells (1964) and Putschar (1966) were doubtful about its significance. It has been suggested that it was either a response to infection or trauma; however, Sandison (1968) was of the opinion that it was impossible to reach a conclusion about its significance.

In summary, non-specific inflammatory changes were seen in the bones of the vertebral column in Ancient Egypt and Nubia, but it would seem impossible to assess their significance in the present state of our knowledge. This latter point should be stressed. Mantle (1959) has pointed a way for future study with his description of the 


\section{J. B. Bourke}

clinical and radiological findings in patients with non-tuberculous infections of the spine. He reported detectable radiological signs in spondylitis from acute pyogenic infection, typhoid, brucellosis, syphilis, yaws, fungus infections and hydatid disease. A comparative radiological study of palaeopathological specimens might be the first step in establishing the nature of the changes at present attributed to non-specific infection.

\section{Specific Infections}

\section{(a) Tuberculosis}

Bourke (1967) in reviewing the causative organisms of infective lesions of the vertebral column in contemporaneous clinical practice noted that the tubercule bacillus was the invariable infecting agent. Sepsis from other organisms was very rare. The typical late pathological changes produced by tuberculous infection in the vertebral column was Pott's Disease. This resulted in bony ankylosis of areas of the vertebral column. The enthusiasm to equate all infective bone pathology in the vertebral column with tuberculosis must be tempered by Luck's (1950) comment that 'The clinical diagnosis of skeletal tuberculosis is not a simple matter, and according to published statistics a substantial percentage of error occurs even in the best orthopaedic clinics'. Girdlestone (1940) and Steindler (1952) were of a similar opinion. However, the danger of extrapolation from modern to former times must be acknowledged.

Unmistakable evidence of tuberculosis of the vertebral column was found in the 21st-dynasty mummy Nesperehân. (Elliot Smith and Ruffer, 1910; and Cave 1939). There was destruction of the lower thoracic and upper lumbar vertebrae which created an angular kyphotic deformity. A right psoas abscess cavity was present but acid fast bacilli could not be demonstrated. Sandison (1968) on reviewing the available data concluded that this example settled beyond doubt the antiquity of tuberculosis in Ancient Egypt and Nubia. However, Morse (1967) advanced the opinion that tuberculosis was established by predynastic times and was certainly in evidence by early dynastic times.

Derry (1938) reported nine examples of spinal tuberculosis and Salib (1962) noted that the lumbar region was the area of the vertebral column most frequently involved. Rowling (1960) reported four further specimens showing presumed spinal tuberculosis in remains from Nubia. They were re-examined by Morse, Brothwell and Ucko (1964) who added two further examples. All showed changes compatible with tuberculous infection. On reviewing all the available evidence Morse and his associates (Morse, Brothwell and Ucko, 1964) accepted thirty-one examples of spinal tuberculosis in Ancient Egypt and Nubia dating as far back as 3000 B.C.

It is probable that the presently known specimens represented but a small number of the total population afflicted with tuberculosis. However, if Luck's caution was valid in Ancient Egypt and Nubia even the thirty-one cases at present accepted would be reduced; some being reclassified as due to staphylococci.

\section{(b) Leprosy}

Leprosy is another specific disease caused by a mycobacterium; and there has been confusion about its diagnosis in palaeopathological specimens which Møller-Christensen (1961) has done much to resolve. The first reported example in Ancient Egypt and 


\section{Palaeopathology of the Vertebral Column in Ancient Egypt and Nubia}

Nubia was of an early Christian period specimen which showed the typical changes in the hands and feet (Elliot Smith and Dawson, 1924); no changes were present in the vertebral column.

\section{(c) Syphilis}

No clear evidence for the existence of syphilis in Ancient Egypt and Nubia was recorded in the large amount of skeletal remains which have so far been examined (Sandison, 1968).

\section{(d) Poliomyelitis}

Poliomyelitis is a viral infection which attacks the anterior horn cells of the spinal column. The presence of this infection in palaeopathological material can only be inferred from the presence of deformity in those who survived the acute phase of the disease. Mitchell (1900) reported an early Egyptian specimen from Deshasheh with shortening of the left leg which he ascribed to poliomyelitis. Sandison (1968) was unimpressed with this and two further examples: one described by Elliot Smith (1912: the club foot of Pharaoh Siptah) and the other by Cameron (1910, the foot deformity of Khnumu-Nekht). It is possible that the deformity might be due to poliomyelitis, but this diagnosis must remain very doubtful. If viral inclusion bodies in the anterior horn cells of the spinal cord were present with this deformity, more credence might be given to the tentative diagnosis.

\section{Endocrine and Metabolic Diseases}

Alkaptonuria was estimated to have an occurrence rate of about one person per million in the British Isles (Gray, 1967). In this recessive genetic disease the intervertebral discs can be calcified, the disc space reduced and the adjacent vertebrae may show rarification on radiological examination. Simon and Zorab (1961) found a Roman period mummy which showed the radiological changes of the ochronotic stage of alkaptonuria. With increasing radiological examination of mummies further examples of this disease were discovered. However, Gray (1967) was subsequently able to show that the radiological changes were produced by the embalming process and not by alkaptonuria. This is an excellent example of the care that must be taken when evaluating new palaeopathological data.

Sandison (1968) and Ghalioungui (1963) were of the opinion that rickets was unknown in Ancient Egypt,

Dewey (1968) has recently developed a method for the quantitation of osteoporosis. He used direct measurements of the femoral cortical bone, but this method could easily be utilized to study vertebrae. He found that the Nubian females showed a rapid and significant loss of bone compared to males. When the data was corrected for stature a similar finding was obtained (Armelagos, 1969). The results of further studies are necessary before an assessment of the usefulness of this technique can be made.

DISCUSSION

The range of pathology found in the vertebral column in Ancient Egypt and Nubia has been described. This anatomical structure was selected for review as it comprises both fibrocartilagenous and synovial joints which can be studied during the examination 


\section{J. B. Bourke}

of one group of bones. Since it is also divided morphologically and anatomically into smaller units, the relative effects of pathological changes on different areas of the vertebral column can be compared one with the other. This technique has been used by Stewart (1966), Bourke (1967 and 1971) and Armelagos (1969) and further exploitation should provide useful data.

There are obviously many blank areas in our knowledge. This has in part been produced by circumstance. Petrie and his colleagues excavated extensively in the period around 1900. The principal part of the skeletal remains which they wished to save was the skull and only the post cranial skeleton if the changes were gross (Salib, 1967). This has produced two limitations. Firstly there are few post cranial bones with which to associate the skulls and secondly since only gross post cranial pathology was saved, many of the minor changes were overlooked and the possibility of population studies rendered impossible. This in part may explain why little data is available for the congenital anomalies of the vertebral column. It is to be hoped that in future, if the post cranial bones cannot be saved, they will at least be studied before reinterment at the site of excavation. Armelagos (1969) used this method in his recent Nubian excavations.

Throughout all sections of the review the difficulty of diagnosis was apparent. Many specimens have been described in the past as showing gross and typical pathological changes. In most the subsequent re-examination has cast doubts on, or even changed the original diagnosis. Almost without exception re-examination has increased the doubt about palaeopathology rather than clarified it (Wells, 1964). This is well shown in the section on neoplasms. It is thus obvious that diagnostic standards are rising. No longer is a description with a photograph acceptable. Wherever possible the techniques of the modern pathological laboratory should be used. Radiography, slab radiography after band saw section, microscopy and electron microscopy are all being increasingly used (Sandison, 1967 and 1968; Bourke, 1967 and 1971 ; Armelagos, 1969; Race et al., 1968).

The care with which interpretation must be undertaken has been demonstrated in the story of alkaptonuria. Descriptions of a common incidence of this recessive genetic metabolic disorder started to appear in the literature in about 1960 . However, it was not until Gray (1967) undertook his studies that it was shown that the changes could be accounted for by the embalming process rather than the genetic disease. Further demonstration of the care with which studies must be conducted was given by Morse et al. (1964). They could only accept a very small number of examples of tuberculosis of the spinal column, many after re-examination. If Luck's comment about the error in current clinical practice being to overestimate rather than underestimate the frequency of tuberculosis was applicable to Ancient Egypt and Nubia, this small group of thirty-one examples would be even further reduced.

The complete scientific objectivity of the palaeopathologist is required to assess the changes in bones, radiographs and pathological slides. The absence of this attitude was shown by the possible example of a rectal tumour or a chordoma described by Elliot Smith and Derry (1910). The latter is exceptionally rare, but was given as the alternative diagnosis without any other possible differential diagnoses being suggested or discussed. 


\section{Palaeopathology of the Vertebral Column in Ancient Egypt and Nubia}

The population studies of Bourke (1967 and 1970) and Armelagos (1969) demonstrated that the distribution of osteophytosis in Ancient Egypt and Nubia was comparable with that seen in other populations. It was remarkable that the distribution of osteophytosis in different populations at different times has shown such a constant pattern. This degeneration was well known even in palaeontology for the Upper Pleistocene Neanderthal man from La Chapelle-aux-Saint showed gross changes of osteophytosis and osteoarthritis (Strauss and Cave, 1957).

Palaeopathology has been increasingly using the detailed methods of modern pathology (Sandison, 1968). The limitations of previous descriptions are being increasingly recognized and the uncomfortable task of re-examination undertaken. This has often increased rather than clarified the doubt and many of the former claims for specimens cannot now be substantiated. This has reduced the range of pathology that can be recognised in the Ancient Egyptians and Nubians. Following the present reduction of accepted palaeopathological specimens the way forward may follow based on objective description and full scientific investigation.

\section{CONCLUSION}

This review of the palaeopathology of the vertebral column in Ancient Egypt and Nubia showed that a sophisticated knowledge of trauma of the vertebral column existed about 5,000 years ago. Infective diseases were present: evidence for tuberculosis being particularly strong. Syphilis was unknown. Neoplastic disease of the vertebral column may also have been present. The same degenerative diseases of the fibrocartilagenous and synovial joints were seen in the Ancient Egyptians and Nubians as in modern populations.

By re-examination and the application of modern diagnostic methods to specimens of the vertebral column from Ancient Egypt and Nubia the number of pathological diagnoses which can withstand criticism has been progressively reduced. However, it may be that a foundation has been prepared from which the range of pathological diagnoses can be enlarged and increased with the collection of specimens by excavators and their detailed scientific examination. Thus may our knowledge of the palaeopathology of the Ancient Egyptians and Nubians be increased.

\section{SUMMARY}

The palaeopathology of the vertebral column in Ancient Egypt and Nubia is reviewed. A refined knowledge of trauma was evident over 4,000 years ago. Population studies particularly of osteoarthritis and osteophytosis, allowed comparison between groups to be attempted. After reappraisal the reliability of many former diagnoses was questioned: with modern techniques greater accuracy may now be possible.

\section{REFERENCES}

Armelagos, G., 'Diseases in Ancient Nubia', Science, 1969, 163, 255.

BARCLAY-SMITH, E., 'Multiple anomaly in a vertebral column', J. Anat., 1911, 45, 144.

BleYER, A., 'The antiquity of achondroplasia', Ann. med. Hist., 1940, 2, 306.

BOURKE, J. B., 'A review of the palaeopathology of the arthritic diseases', chapter 27 in Diseases in Antiquity, ed. by D. R. Brothwell, and A. T. Sandison, Springfield, Thomas, 1967. 


\section{J. B. Bourke}

BoURKe, J. B., 'Trauma and Degenerative Diseases in Ancient Egypt and Nubia', in The Population Biology of the Ancient Egyptians and Nubians, ed. by D. R. Brothwell and B. Chiarelli, Accademie Press, 1971 (in the press).

Braasted, J. H., The Edwin Smith Surgical Papyrus, Chicago, University of Chicago Press, 1930.

Brothwel, D. R., 'The Evidence for Neoplasms', chapter 24 in Diseases in Antiquity, op. cit., 1967a.

Brothwell, D. R. 'Major Congenital Anomalies of the Skeleton: Evidence from Earlier Populations', chapter 34 in Diseases in Antiquity, op. cit., $1967 \mathrm{~b}$.

Brothwel, D. R., and Powers, R., 'Congenital Malformations of the Skeleton in Earlier Man', in The Skeletal Biology of Earlier Human Populations, ed. D. R. Brothwell, London, Pergamon, 1968.

Cameron, J., 'Report on the anatomy of the mummies', in The Tomb of Two Brothers' ed. by M. A. Murray, Manchester, Sherrat and Hughes, 1910.

CAve, A. J. E., 'The Evidence for the incidence of tuberculosis in Ancient Egypt', Brit. J. Tuberc. Dis. Chest, 1939, 33, 142.

DAwson, W. R., 'The earliest surgical treatise', Brit. J. Surg., 1932, $20,34$.

Dawson, W. R., 'The Egyptian Medical Papyri', in Science, Medicine and History: Essays on the evolution of scientific thought and Medical Practice written in honour of Charles Singer, ed. by E. A. Underwood, London, Oxford University Press, 1953.

DerRY, D. E., 'Anatomical report', Archaeological Survey of Nubia Bull., 1909, 3, 29.

DerRy, D. E., 'Pott's Disease in Ancient Egypt', Med. Press, 1938, 197, 1.

DEWEY, J. R., Thesis-University of Utah, 1968. Quoted by Armelagos (1969).

Eunot Smrth, G., The Royal Mummies. Catalogue General des Antiquités Égyptiennes du Musée du Caire, 1912.

Euliot Smit, G., and Dawson, W. R., Egyptian Mummies, London, Allen and Unwin, 1924.

Elluot SMrth, G., and DerRY, D. E., 'Anatomical Report', Archaeological Survey of Nubia Bull., 1910, 5, 11.

Euliot SMrth, G., and RufFer, M. A., 'Pott'sche Krankheit an einer Agyptschen Mumie aus der Zeit der 21 Dynastie (Um 1000 U. Chr.)', in Zur historischen Biologie der Krankheitserrgen, ed. by Sudhoff and Sticker, Giessen, Heft 3, 1910.

EuLot SMrth, G., and Wood JoNes, F., 'Report on the Human Remains', The Archaeological Survey of Nubia, 1907-1908, Cairo, National Printing Department, 1910.

Ghalloungui, P., Magic and Medical Science in Ancient Egypt, London, Hodder \& Stoughton, 1963.

GIRDlestone, G. R., Tuberculosis of Bone and Joint, New York, Oxford University Press, 1940.

Gray, P. H. K., 'Calcinosis Intervertebralis with special reference to similar changes found in mummies in Ancient Egypt', Chapter 2 in Diseases in Antiquity, op. cit.

Inglemark, B. E., Møller-Christensen, V., and Brinch, O., 'Spinal joint changes and dental infections', Acta. Anat., 1959, 38 (Suppl. 36).

Johnston, F. E., 'Achondroplastic dwarfs through history', Clin. Pediat., 1963, 2, 703.

JoNEs, E. W. A. H., 'Studies in achondroplasia', J. Anat., 1932, 66, 565.

JoNEs, W. H. S., Epidemics by Hippocrates, ed. by W. H. S. Jones, Loeb Classical Library, $1922,1,144$.

KrLLGREN, J. H., 'Osteoarthritis in patients and populations', Brit. med. J., 1961, ii, 1.

Luck, J. V., Bone and Joint Diseases. Springfield, Thomas, 1950.

MACIVER, R., The Earliest Inhabitants of Abydos. Oxford, Clarendon Press, 1901.

MANTLE, J. A., 'Non-tuberculous infections of the spine', chapter 7 in Modern Trends in Diseases of the Vertebral Column, ed. by R. Nassim, and H. Jackson Burrows, London, Butterworth, 1959.

MCKern, T. W., and Stewart, T. D., Skeletal Changes in Young American Males. Technical Report. Headquarters Research and Development Command, Natick. Mass, 1957.

MerCer, W., and DUTHIE, R. B., Orthopaedic Surgery, London, Arnold, 1964. 


\section{Palaeopathology of the Vertebral Column in Ancient Egypt and Nubia}

Mrrchell, J. K., 'Study of a mummy affected with anterior poliomyelitis', Trans. Ass. Am. Physns, 1900, 15, 134.

MølleR-Christensen, V., Bone Changes in Leprosy, Copenhagen, Munksgaard, 1961.

Moodre, R. L., Paleopathology. An Introduction to the Study of Ancient Evidences of Disease, Urbana, University of Illinois Press, 1923.

Morse, D., 'Tuberculosis', chapter 19 in Diseases in Antiquity, op. cit.

Morse, D., Brothwell, D. R., and UCKo, P. J., 'Tuberculosis in Ancient Egypt', Amer. Rev. resp. Dis., 1964, 90, 524.

PetrIE, W. M. F., Diospolis Parva (The Cemeteries of Abadiyeh and Hu), London, Special Extra Publication of the Egypt Exploration Fund, 1901.

POWER, D., 'Some early surgical cases', Brit. J. Surg., 1933, $21,1$.

Putschar, W. G. J., 'Problems in the Pathology and Palaeopathology of Bone', chapter in Human Palaeopathology, ed. by S. Jarcho, New Haven, Yale University Press, 1966.

RACe, G. J., Fry, E. I., MATTHews, J. L., WAgner, M. J., MArtin, J. H., and LYNN, J. A., 'Ancient Nubian Human Bone: a chemical and ultrastructural characterization including collagen', Am. J. Phys. Anthrop., 1968, 28, 157.

Rowling, J. T., 'Disease in Ancient Egypt: Evidence from Pathological Lesions found in Mummies', M. D. thesis, University of Cambridge, 1960.

Rowling, J. T., 'Pathological changes in mummies', Proc. $R$. Soc. Med., 1961, 54, 409.

Rowlnng, J. T., 'Paraplegia', chapter 20 in Diseases in Antiquity, op. cit.

RUFFE, M. A., 'On dwarfs and other deformed persons', Bull. Soc. Archeol. d'Alexandrie, $1911,13,1$.

RuFrer, M. A., 'Arthritis deformans and spondylitis in Ancient Egypt', J. Path. Bact., 1918, $22,152$.

RuFfer, M. A., Studies in the Paleopathology of Egypt, Chicago, University of Chicago Press, 1921.

Ruffer, M. A., and RIETt, A., 'On osseous lesions in Ancient Egypt', J. Path. Bact., 1912, $16,439$.

SALB, P., 'Orthopaedic and traumatic skeletal lesions in Ancient Egyptians', J. Bone Jt Surg., $1962,44 B, 944$.

SAliB, P., 'Trauma and Disease of the Post Cranial Skeleton in Ancient Egypt', chapter 47 in Diseases in Antiquity, op. cit.

Sandison, A. T., 'Degenerative Vascular Disease', chapter 39 in Diseases in Antiquity, op. cit.

SANDISON, A. T., 'Pathological changes in the skeletons of earlier populations due to acquired disease and difficulties in their interpretation', in The Skeletal Biology of Earlier Human Populations, ed. by D. R. Brothwell, London, Pergamon, 1968.

Simon, G., and ZoraB, P. A., 'The radiographic changes in alkaptonuric arthritis', $B r$. $J$. Radiol., 1961, 34, 384.

STEINDLER, A., 'Postgraduate lecture on orthopaedic diagnosis and indications', in Tuberculosis of the Skeletal System, Section A, Volume III, Springfield, Thomas, 1952.

STEwart, T. D., 'Racial patterns in vertebral osteoarthritis', Am. J. Phys. Anthrop., 1947, $5,433$.

Strwart, T. D., 'Some problems in Human Palaeopathology', chapter in Human Palaeopathology, op. cit.

Straus, W. L., Jr., and CAVE, A. J. E., 'Pathology and posture of Neanderthal man', Q. Rev. Biol., 1957, 32, 348.

Wrus, C., Bones, Bodies and Disease, London, Thames \& Hudson, 1964.

WIILIs, T. A., 'The age factor in hypertrophic arthritis', J. Bone Jt Surg., 1924, 6, 316.

ZORAB, P. A., 'The historical and prehistorical background to ankylosing spondylitis', Proc. R. Soc. Med., 1961, 54, 415. 